\title{
Topographic and forest-stand variables determining epiphytic lichen diversity in the primeval beech forest in the Ukrainian Carpathians
}

\author{
Lyudmyla Dymytrova • Olga Nadyeina • Martina L. Hobi • \\ Christoph Scheidegger
}

Received: 5 March 2013/Revised: 25 February 2014/Accepted: 7 March 2014/

Published online: 30 March 2014

(C) Springer Science+Business Media Dordrecht 2014

\begin{abstract}
The Uholka-Shyrokyi Luh area of the Carpathian Biosphere Reserve is considered the largest and the most valuable primeval beech forest in Europe for biodiversity conservation. To study the impact of different topographic and forest-stand variables on epiphytic lichen diversity a total of 294 systematically distributed sampling plots were surveyed and 198 epiphytic lichen species recorded in this forest landscape, which has an uneven-aged structure. The obtained data were analysed using a non-metric multidimensional ordination and a generalized linear model. The epiphytic lichen species density at the plot level was mainly influenced by altitude and forest-stand variables. These variables are related to both the light availability i.e. canopy closure, and the habitat diversity, i.e. the developmental stage of the forest stands and the mean stem diameter. We found that lichen species density on plots with a relatively open canopy was significantly higher than on plots with a fairly loose or closed canopy structure. The late developmental stage of forest stands, which is characterized by a large number of old trees with rough and creviced bark, had a strong positive effect on lichen species density. In the Uholka-Shyrokyi Luh primeval forest the mean stem diameter of beech trees significantly correlated with lichen species density per plot. Similar trends in the species diversity of nationally red-listed lichens were revealed. Epiphytic lichens with a high conservation value nationally and
\end{abstract}

Communicated by T. G. Allan Green.

L. Dymytrova $(\bowtie) \cdot$ O. Nadyeina

M.H. Kholodny Institute of Botany, Tereshchenkivska 2, Kyiv 01601, Ukraine

e-mail: ldymytrova@gmail.com

O. Nadyeina

e-mail: nadyeina@gmail.com

L. Dymytrova $\cdot$ O. Nadyeina · M. L. Hobi · C. Scheidegger

Swiss Federal Institute for Forest, Snow and Landscape Research (WSL), Zürcherstrasse 111, 8903 Birmensdorf, Switzerland

e-mail: martina.hobi@wsl.ch

C. Scheidegger

e-mail: christoph.scheidegger@wsl.ch 
internationally were found to be rather abundant in the Uholka-Shyrokyi Luh area, which shows its international importance for the conservation of forest-bound lichens.

Keywords Lichenized fungi - Primeval forest - Fagus sylvatica · Topographic and forest-stand factors · Carpathian Biosphere Reserve · Ukraine

\section{Introduction}

European beech forests have been the subject of continuing ecological, paleoecological and genetic research in recent decades due to their wide distribution and high economic importance (Magri et al. 2006). The remnant primeval beech forests are particularly interesting objects for forest research as they provide excellent and necessary conditions for studying and understanding ecosystem processes in forests where no human intervention has occurred for a long time. The Carpathians are a kind of locus classicus for virgin beech forest studies in Europe (Commarmot et al. 2013).

The largest primeval beech forest in Europe is the Uholka-Shyrokyi Luh (over 10,000 ha) in the Ukrainian Carpathians which was added to UNESCO'S World Heritage list in 2007 (Commarmot et al. 2013). Due to the absence of navigable rivers, steep slopes and their remoteness, the beech forests in the area have remained unaffected by logging, but they were used for other human activities, especially hunting and gathering (Brändli and Dowhanytsch 2003). These unique forests have been preserved by assigning them a conservation status. The first forest reserve was founded in the Shyrokyi Luh area («Lužanský prales») in 1936 by the Czechoslovakian Republic. In 1958 the government of the Ukrainian Soviet Republic created the Uholka forest reserve. In 1970 and 1980s both areas were included in the newly founded Carpathian Reserve (Hamor and Berkela 2011).

The primeval forest of Uholka-Shyrokyi Luh has an outstanding importance for biodiversity conservation and is now strictly protected. The spatio-temporal forest connectivity on the landscape scale is intact and includes a small mosaic of forest developmental stages with patches ranging from young to old. It is characterised by collapsing stands, a small-scale uneven-aged and multilayered stand structure with a wide range of tree diameter (up to $150 \mathrm{~cm} \mathrm{DBH}$ ) and a large amount of deadwood and veteran trees (up to 500 years old) (Trotsiuk et al. 2012; Commarmot et al. 2013; Hobi 2013).

Old-growth beech forests harbour a specific lichen biota which includes many red-listed species and indicators of woodland key habitats (Sillet et al. 2000; Coppins and Coppins 2002; Printzen et al. 2002; Kondratyuk and Coppins 2000). Since such beech forests have a high conservation status in Europe (Brändli and Dowhanytsch 2003; Fritz et al. 2008b), lichen diversity and its determining environmental factors have been investigated intensively (Pirintsos et al. 1995; Aude and Poulsen 2000; Nascimbene et al. 2007; Fritz et al. 2008b; Fritz 2009; Moning and Müller 2009 etc.). Researches on lichen biota in the primeval beech forests of the Ukrainian Carpathians have, however, hitherto been limited to floristic studies (Navrotska 1984; Kondratyuk and Coppins 2000; Kondratyuk et al. 2003; Vondrák et al. 2010; Dymytrova et al. 2013 etc.).

Thus, the aim of our research was to evaluate the relative influences of environmental variables on species richness, density and composition of epiphytic lichens in the primeval beech forest of the Ukrainian Carpathians. Specifically, the following research questions were addressed: (1) How do topographic and forest-stand variables affect lichen species density at the plot level in the primeval beech forest? (2) What are the most important factors determining the distribution of red-listed lichens in the study area? 


\section{Materials and methods}

Study area

The Uholsko-Shyrokoluzhanskyi massif is situated in the south-western part of Ukraine $\left(48^{\circ} 18^{\prime} 22^{\prime \prime} \mathrm{N}, 23^{\circ} 41^{\prime} 46^{\prime \prime} \mathrm{E}\right)$ and belongs to the Eastern Carpathian Mountains (Fig. 1). It is located on the southern and eastern slopes of the Menchul Mountain (1,501 m) and on the southern slopes of Krasna ridge (400-1,400 m). The almost pure beech forest includes two contiguous areas: Uholka and Shyrokyi Luh, which are protected within the Carpathian Biosphere Reserve. The massif is located between 400 and 1,400 $\mathrm{m}$ a.s.l. and consists mainly of flysch layers with Jurassic limestone, calcareous conglomerates, marls and sandstone (Commarmot et al. 2013). The slopes are rather steep with a mean inclination of 27-58 \% (rarely up to $84 \%$ ) (Hnatiuk and Zinko 1997). The Shyrokyi Luh area is dominated by north- and east-exposed slopes, while in the Uholka area less steep and mainly south-exposed slopes are frequent (Commarmot et al. 2013). The climate is temperate and characterized by an annual average temperature of $+7.7^{\circ} \mathrm{C}$. The mean temperature in July is $+17.9{ }^{\circ} \mathrm{C}$ and in January $-2.7^{\circ} \mathrm{C}$, measured at the meteorological station of the Carpathian Biosphere Reserve in Uholka at $430 \mathrm{~m}$ altitude (Commarmot et al. 2013). In Shyrokyi Luh the annual temperatures are slightly lower than in Uholka (Bursak 1997). The annual average precipitation at the same meteorological station in Uholka was 1,134 mm (from 1980 to 2010) (Commarmot et al. 2013). The average air humidity is very high (approx. $85 \%$ ) (Bursak 1997).

Virgin beech forests make up $88 \%$ of the total forest area of the Uholsko-Shyrokoluzhanskyi massif. The timberline is at 1,140 m a.s.1., which is 100-200 m lower than the natural timberline because of human activity in the form of intense livestock pasturing on the mountain meadows (Commarmot et al. 2013). These forest stands are characterized by an uneven-aged and multilayered structure, a high canopy closure and little floristic variety (Sheliag-Sosonko et al. 1997; Commarmot et al. 2005). The median tree age of randomly cored beech trees is 211 in the Uholka and 187 years in the Shyrokyi Luh area and the oldest reliably dated beech tree had an age of 451 years (Trotsiuk et al. 2012; Hobi 2013).

Field methods

The lichens were sampled during July and August 2010, as part of the forest inventory carried out in the primeval beech forest of the Uholsko-Shyrokoluzhanskyi massif within the framework of a cooperation project of the Swiss Federal Institute for Forest, Snow and Landscape Research WSL, the Ukrainian National Forestry University UNFU and the Carpathian Biosphere Reserve (Commarmot et al. 2013). The sampling design of the inventory was a non-stratified systematic cluster sampling (Mandallaz 2008). Each cluster consisted of two sample plots $\left(500 \mathrm{~m}^{2}\right.$; horizontal radius of $\left.12.62 \mathrm{~m}\right) 100 \mathrm{~m}$ apart. The clusters were arranged on a $445 \times 1,235 \mathrm{~m}$ rectangular grid with a randomly chosen starting point. This resulted in a total of 294 plots in the study area. At the sampling plots mainly Fagus sylvatica L., Carpinus betulus L., Acer pseudoplatanus L., Acer platanoides L. and Abies alba Mill. were present. Key advantages of this design compared to a regular grid of single plots are the lower inventory costs including shorter walking distances and the operational advantage in case of emergency that two survey teams could work within alarm distance of each other (Lanz et al. 2013). The spatial autocorrelation within clusters was tested for stem density and tree volume by comparing the empirical variance of the 


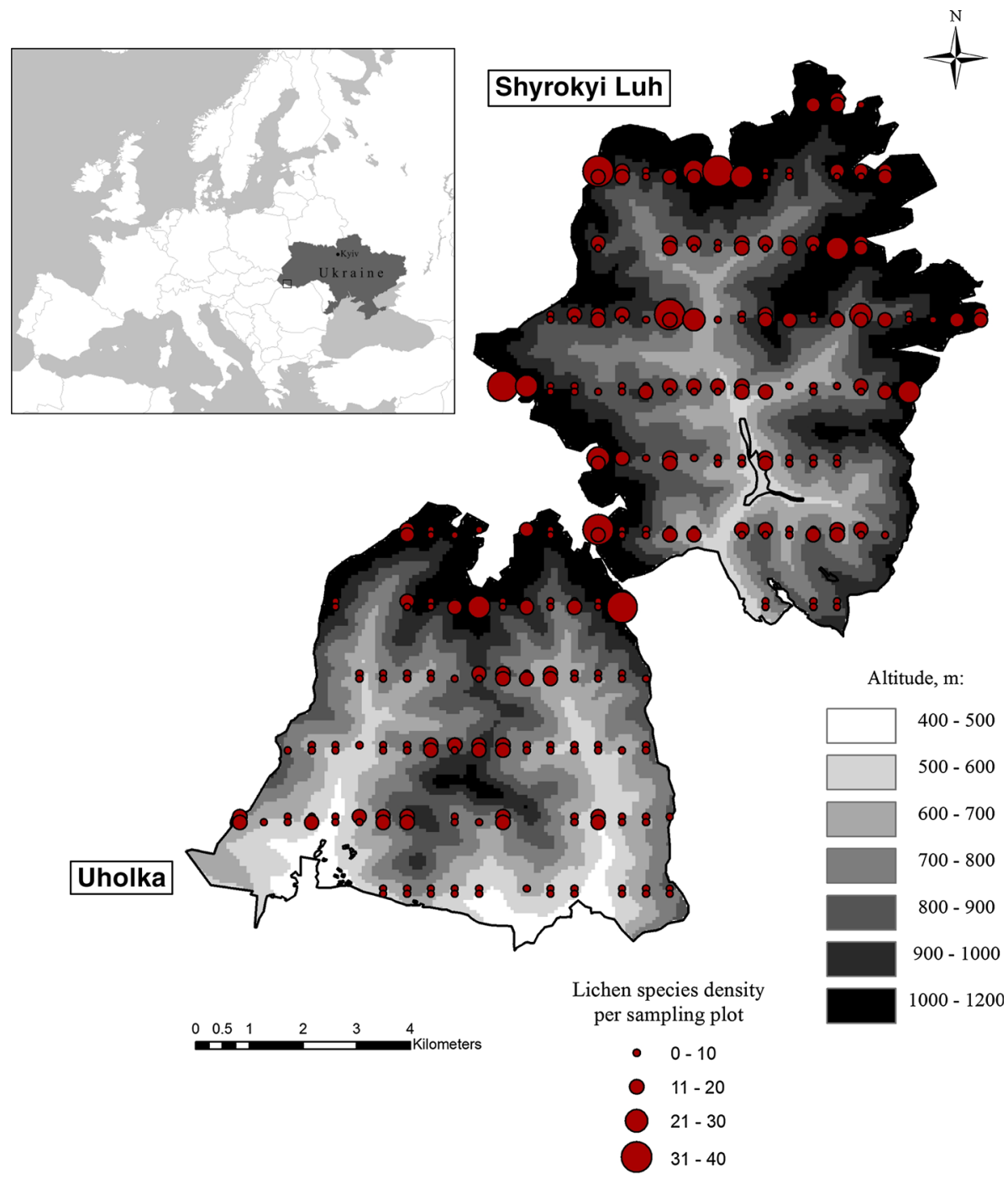

Fig. 1 Lichen species density on 294 sampling plots in the primeval beech forests Uholka-Shyrokyi Luh of the Carpathian Biosphere Reserve

estimates under an estimator ignoring the clustered distribution of sampling plots and an estimator taking the cluster structure into account (Mandallaz 2008). There was only a very small difference between the two variance estimates, and we conclude that the spatial autocorrelation within clusters is very small (Lanz 2011).

On each of the 294 plots (Fig. 1) 5-10 trees with lichen occurrence and DBH $>6 \mathrm{~cm}$ were randomly selected and the epiphytic lichen diversity was assessed. The bark of living and dead-standing trees all around the trunk, from the base up to $2 \mathrm{~m}$, was carefully observed. If possible, the lichens were identified in the field. If they were morphologically very similar and could not be distinguished in the field, they were listed as species aggregates (see Table 4 in Appendix 1). For example, Candelariella xanthostigma aggr. 
includes Candelariella xanthostigma, Candelariella reflexa, Candelariella efflorescens, and Candelariella faginea. Unidentified specimens were collected and later determined under a microscope and by chemical spot tests using different identification keys. All sterile specimens, as well as Cetrelia, Lecanora strobilina, Lecanora polytropa, Ochrolechia pallescens and Parmotrema arnoldii, were determined or checked by thin layer chromatography with solvent system A, B, C (White and James 1985). Nomenclature generally follows "The third checklist of lichen-forming and allied fungi of Ukraine" (Kondratyuk et al. 2010).

The topographic and forest-stand variables (Table 1) were assessed by the survey teams of the forest inventory on each sampling plot, as described in Commarmot et al. (2010, 2013). To describe the forest structure, canopy openness parameters, which reflect the frequency and size of canopy gaps in the upper forest layer, were used. Forest stands characterized by a canopy structure with gaps smaller than one tree crown, were classified as 'closed', and areas with several gaps large enough to fit more than one tree 'scattered'. 'Loose' forest stands were regarded as an intermediate stage with few gaps the size of a canopy tree (Commarmot et al. 2013). In addition, we visually classified the forest stand into three different developmental stages according to the predominant age of the trees on each sampling plot: (1) 'young' if the plot is dominated by densely growing young trees with smooth bark; (2) 'mature' if mostly mature trees with rough bark are present on the plot, and (3) 'overmature' stands if the plots contain very old trees with creviced bark, often covered by mosses and/or damaged by pathogens or natural disturbances such as lightening or strong wind. The different developmental stages of forest stands cover a wide diversity of microhabitats for epiphytic lichens, including those with patchy light availability, diverse bark structures, and enough stability for lichen species to develop and reproduce over several decades, i.e. over several lichen generations.

\section{Statistical analyses}

Statistical analyses were carried out with R version 2.13.1 (The R Foundation for Statistical Computing, 2011). Maps were drawn using ArcMap 8 (ESRI).

Two datasets were statistically analysed at the plot level. The first set consisted of data on lichen species composition (presence/absence data) collected on 294 sampling plots (294 plots $\times 171$ species), and the second of two response variables and 11 environmental variables, divided into two groups: (1) topographic (four variables) and (2) forest-stand parameters (seven variables) (Table 1). Some variables, e.g. tree species were omitted from analysis due to their low variability. Correlations between the environmental variables and the lichen species density were calculated with Spearman correlation coefficient.

Non-metric multidimensional analysis (NMDS) was performed to describe the lichen species composition on beech trunks within sampling plots using the $\mathrm{R}$ package vegan (Oksanen et al. 2012). This ordination method is very suitable for analysing the relationships among objects in large datasets, as well as for effectively describing non-linear species responses on different ecological gradients (Borcard et al. 2011; Oksanen 2011). Only lichen species with more than five observations were included in this analysis because rare species usually have an unduly high influence on the ordination results (Oksanen et al. 2012). The Bray-Curtis distance measured with 50 runs with 200 iterations was used. Correlations between the environmental variables and the ordination axes were calculated with the Pearson correlation coefficient. The NMDS ordination of lichen species composition was interpreted with statistically significant environmental variables $(p<0.05)$. 
Table 1 Description of the environmental variables and the responses used in the analyses

\begin{tabular}{|c|c|c|}
\hline Variables & Scale & Description \\
\hline \multicolumn{3}{|c|}{ Topographic parameters at plot level (4) } \\
\hline Altitude & Continuous & Elevation above sea level at the sampling plot in $\mathrm{m}$ \\
\hline Aspect & Continuous & Exposition at the sampling plot in gon \\
\hline Slope & Continuous & Mean inclination of the slope at the sampling plot in $\%$ \\
\hline Relief & Ordinal & $\begin{array}{l}\text { Position of the sampling plot on the slope: } 1 \text { bottom; } 2 \text { lower; } 3 \text { middle; } 4 \\
\text { upper; } 5 \text { ridge }\end{array}$ \\
\hline \multicolumn{3}{|c|}{ Forest-stand parameters at plot level (7) } \\
\hline $\begin{array}{l}\text { Canopy } \\
\text { cover }\end{array}$ & Continuous & Estimated total canopy cover on the sampling plot in $\%$ \\
\hline Mean DBH & Continuous & $\begin{array}{l}\text { Mean diameter at breast height }(1.3 \mathrm{~m}) \text { of the measured trees on the } \\
\text { sampling plot in } \mathrm{cm}\end{array}$ \\
\hline Forest stage & Ordinal & $\begin{array}{l}\text { The developmental stage of forest stands on sampling plots: } 1 \text { young; } 2 \\
\text { mature; } 3 \text { overmature }\end{array}$ \\
\hline $\begin{array}{l}\text { Lying } \\
\text { deadwood }\end{array}$ & Continuous & $\begin{array}{l}\text { Total volume of lying deadwood sampled with a line intersect method in } \\
\mathrm{m}^{3} / \mathrm{ha}\end{array}$ \\
\hline $\begin{array}{l}\text { Canopy } \\
\text { closure }\end{array}$ & Ordinal & $\begin{array}{l}\text { Aggregation of tree crowns in the upper canopy layer on the sampling plot: } \\
1 \text { closed; } 2 \text { loose; } 3 \text { scattered }\end{array}$ \\
\hline Tree number & Continuous & Number of living trees $\geq 6 \mathrm{~cm}$ DBH per sampling plot \\
\hline Tree species & Nominal & $\begin{array}{l}\text { Tree species growing on sampling plots: } 1 \text { Fagus sylvatica; } 2 \text { F. sylvatica } \\
\text { and Acer pseudoplatanus; } 3 \text { F. sylvatica and Abies alba; } 4 \text { A. alba; } 5 \text { F. } \\
\text { sylvatica and Acer platanoide }\end{array}$ \\
\hline \multicolumn{3}{|l|}{ Responses (2) } \\
\hline Lichen_SD & Continuous & Lichen species density on the sampling plot \\
\hline Redlisted_SD & Continuous & Red-listed lichen species density on the sampling plot \\
\hline
\end{tabular}

To assess the effect of environmental variables on the lichen species density, generalized linear models (GLM) were created on the basis of the second dataset using standard R functions. Total lichen species density was analyzed by Poisson distribution with log-linear regression. The density of red-listed lichen species was transformed into presence/absence values and then a binomial distribution with logistic regression was applied. At first all variables were added to the model by the forward stepwise procedure using the Akaike Information Criterion (AIC) as the selection parameter. Then statistically insignificant variables $(p>0.05)$, e.g. lying deadwood, slope, aspect and relief, were manually removed. Additionally the percentage of variation explained by each GLM model was calculated.

Tukey's HSD test for uneven groups was applied to test for significant differences in the mean lichen species density between groups of the developmental stages and the canopy closure of forest stands. Indicator values for each lichen species for different forest stage classes were calculated (Roberts 2011). All species with a total number of records $<3$ were omitted from this analysis.

Environmental variables at plot level

Nearly $70 \%$ of the sampling plots were situated between 600 and 1,000 m a.s.l. The lowest plot was at $458 \mathrm{~m}$ in the Uholka area and the highest at 1,269 $\mathrm{m}$ in the Shyrokyi Luh area. More than $80 \%$ of the 294 sampling plots studied were located in the middle 
(122) or upper parts of slopes (97), while 13 plots were on mountain ridges, 49 on the lower parts of slopes and only 13 plots at the bottom of valleys. The mean inclination of slopes was $50 \%$ and varied from 4 to $90 \%$. Nearly $80 \%$ of the plots were shaded habitats with a total canopy cover of 70-100\% and only 13 plots had a total canopy cover below $50 \%$.

Lichens were recorded on plots with different stand densities: closed (88 plots), loose (153) and scattered (52). Most of the plots (200) were situated in mature forest stands, while 85 plots were located in young and only nine plots in overmature forest stands. The mean DBH of beech trees per sampling plot was $35 \pm 10.8 \mathrm{~cm}$. The maximum DBH was $113.7 \mathrm{~cm}$, while $92.5 \%$ of the plots had a mean DBH of up to $50 \mathrm{~cm}$. Only one plot with a mean DBH over $70 \mathrm{~cm}$ was analyzed. DBH revealed a strong negative correlation with stem density and the number of trees per sampling plot (Table 2).

\section{Results}

Lichen species density at plot level

A total of 198 epiphytic lichen species were recorded; 160 in Uholka and 166 in Shyrokyi Luh (See Table 4 in Appendix. 1, Fig. 1). The mean number of lichen species per sampling plot was 10.2. According to Tukey's HSD test, the lichen species density at the plot level was significantly higher on plots with a scattered forest canopy (mean density 14.1 per plot) than on plots with a closed (8.7 per plot, $p<0.01$ ) or loose canopy (10.1 per plot, $p<0.01)$. The lichen species density on closed and fairly loose plots was not significantly different (Fig. 2b). Similarly, the lichen species density was significantly higher in overmature $(p=0.01)$ and mature forest stands $(p=0.01)$ than in young forest stands, but not significantly different in mature and overmature forests, with mean lichen species densities (8.6, 10.9 and 14.7) in young, mature and overmature forest stands, respectively (Fig. 2a).

Lichen species density increased steadily along the altitudinal gradient $(r=0.39$, $p<0.05$ ), and was also strongly affected by the forest-stand variables that reflect the light conditions at the plots, e.g. canopy closure $(\mathrm{r}=0.23, p<0.05)$ and canopy cover $(\mathrm{r}=-$ $0.22, p<0.05$ ) (Table 2; Fig. 3). The highest lichen species density per sampling plot (36-40 species per plot) was recorded on beech trees growing near the timberline (over $1,200 \mathrm{~m}$ a.s.1.) in relatively open forest with scattered canopy. Nearly all plots (99\%) with a closed forest canopy had a low lichen species density (below 20 species per plot) and were evenly spread over the entire altitudinal gradient. The lichen species density $>20$ was mostly found on plots with scattered or loose canopy above $800 \mathrm{~m}$ a.s.l. and only once recorded on a plot with closed forest canopy (Figs. 1, 3).

Lichen species density negatively correlated with the number of trees per sampling plots $(\mathrm{r}=-0.19, p<0.05)$, while topographic parameters, e.g. aspect, slope and relief, had no effect on this response variable (Table 2). The amount of lying deadwood on the plots did not significantly affect the species density of epiphytic lichens on the trunks of living and dead-standing trees in studied forest. Our analysis revealed that mean DBH of trees significantly affected the lichen species density per plot $(\mathrm{r}=0.18, p<0.05)$ (Fig. 4; Table 2). The results of GLM analysis confirmed that altitude, mean DBH and a late developmental stage of forest stands (i.e. overmature) were the most important factors influencing the lichen species density on sampling plots (Fig. 5). 


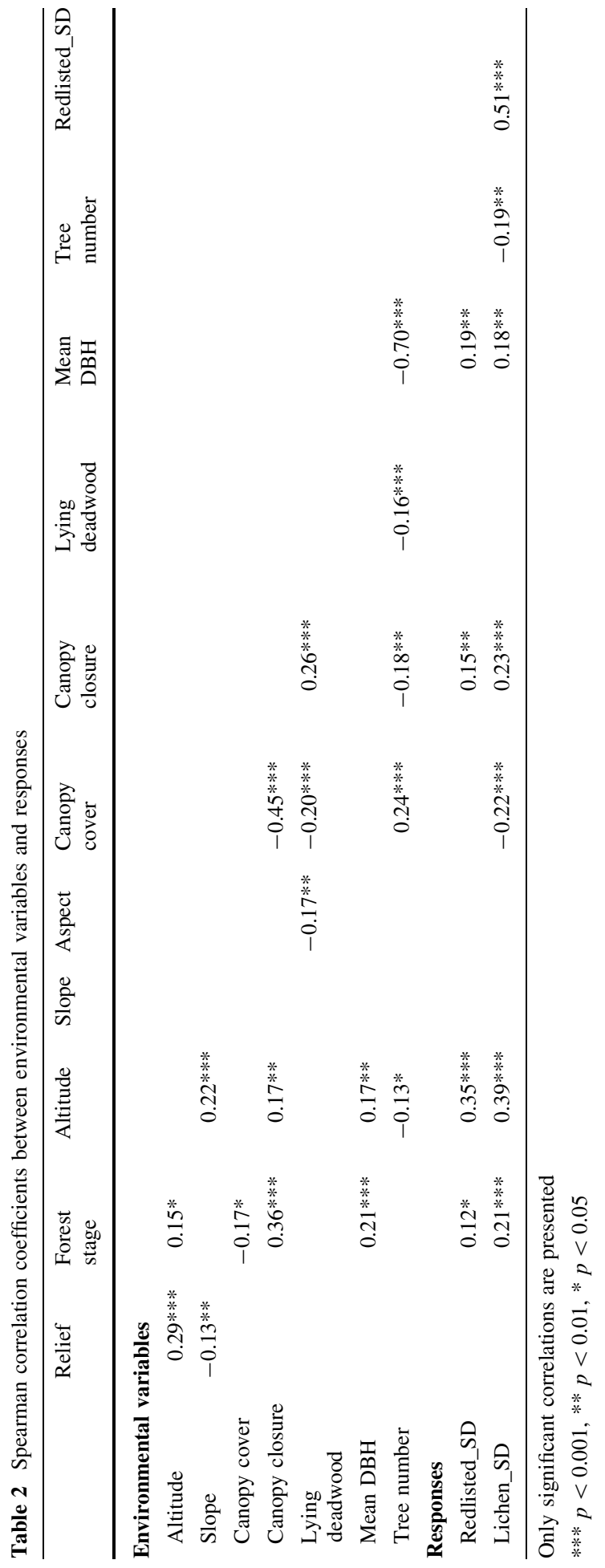



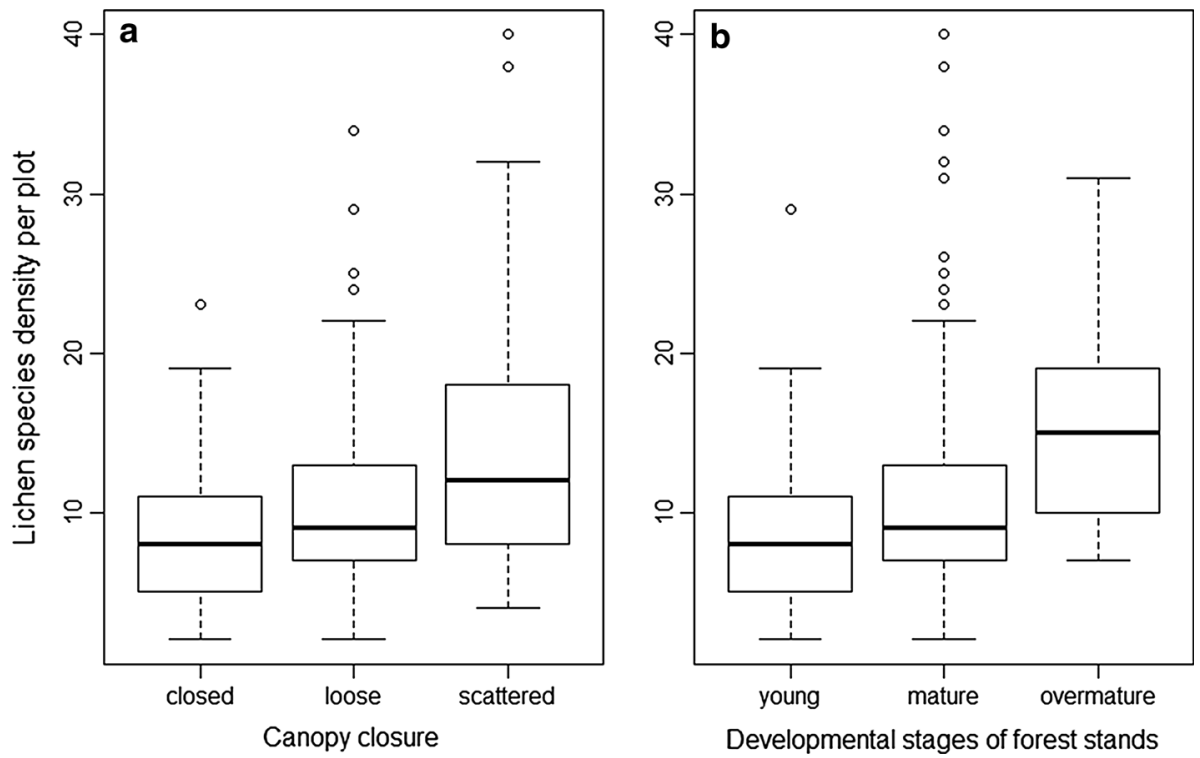

Fig. 2 a Lichen species density at plots with closed $(n=88)$, loose $(n=153)$ and scattered canopy $(n=52), \mathrm{r}=0.23, p<0.05$. b Lichen species density at plots with young $(n=85)$, mature $(n=200)$ and overmature forest stands $(n=9), \mathrm{r}=0.21, p<0.05$

Lichen species composition at plot level

The most frequent lichens in both areas were crustose species, e.g. Phlyctis argena (98\% of plots), Pyrenula nitida (88 \%), Graphis scripta (87\%), Lepraria lobificans aggr. (46\%) and Lecanora argentata (43\%). Approximately $50 \%$ of the total number of species (e.g. 104 lichen species) had low frequencies and were found on less than five sampling plots (See Table 4 in Appendix 1). Forty-three species were recorded only once, 39 were found only in Shyrokyi Luh and 33 only in Uholka. Some species, e.g. Biatora vernalis, Collema flaccidum, Dictyocatenulata alba, Leptogium lichenoides, L. cyanescens, Thelotrema lepadinum and Peltigera praetextata, occurred more frequently in the Shyrokyi Luh area.

The NMDS analysis of the lichen species composition on the sampling plots resulted in a two-dimensional solution with final stress 0.25 , accounting for $47 \%$ of the total variance (Figs. 6, 7). The most important gradient (NMDS axis $2, \mathrm{r}^{2}=0.27$ ) was mainly related to the topographic parameters: aspect and slope, but their effects were very slight. The second gradient (NMDS axis $1, \mathrm{r}^{2}=0.20$ ) was highly correlated with altitude, mean DBH as well as the parameters reflecting light availability (e.g. canopy cover) (Table 3 ). Thus, all these variables influenced the lichen species composition at the plot level. The most important factor, however, was the altitudinal gradient $\left(r=0.94\right.$ to NMDS axis $1, r^{2}=0.21$, $p=0.001$ ).

On the NMDS ordination plot, three groups of lichens were distinguished (Fig. 6). The first was situated on the right of the NMDS ordination and combined lichens growing in open habitats, e.g. Amandinea punctata, Buellia disciformis, Flavoparmelia caperata, Lecanora leptyrodes, Lecidella elaeochroma, Parmelia submontana, Parmelia sulcata, Platismatia glauca and Ramalina fastigiata. The second was on the left of the NMDS ordination and was occupied by lichen species that occur mostly in shaded and rather 

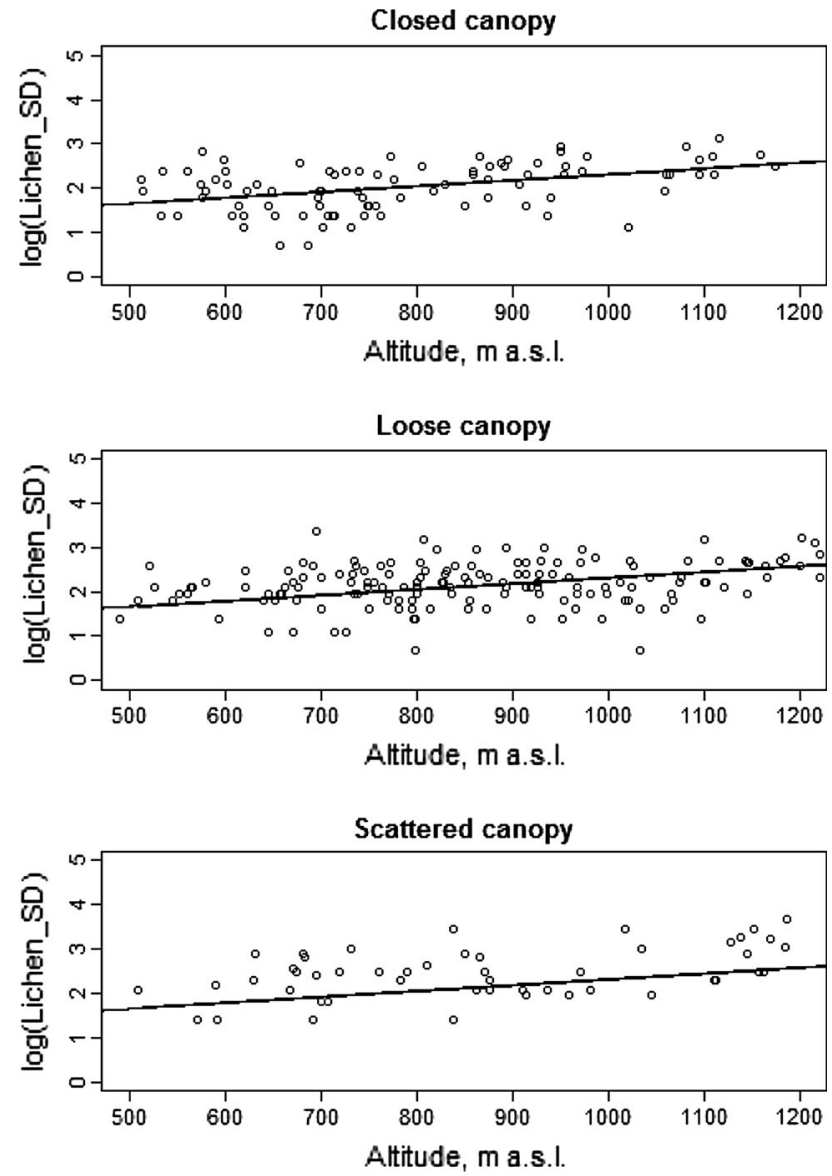

Fig. 3 Lichen species density along the altitudinal gradient on sampling plots with closed $(\mathrm{r}=0.39$, $p<0.001)$, loose $(\mathrm{r}=0.27, p<0.001)$ and scattered $(\mathrm{r}=0.52, p<0.001)$ canopy fitted by a linear regression

humid habitats, including Acrocordia gemmata, Belonia herculina, Collema flaccidum, Gyalecta truncigena, Leptogium cyanescens, Leptogium lichenoides, Thelotrema lepadinum and many others. For example, Parmelia submontana (from the first ordination group) was found in rather open habitats with a canopy cover of 40-75\%, while Gyalecta truncigena (from the second ordination group) preferred shaded habitats with a canopy cover of 50-95\%. The third group (at the centre of NMDS ordination) included very common beech-forest lichens, such as Graphis scripta, Phlyctis argena and Pyrenula nitida, which had a rather wide ecological amplitude.

The developmental stages of the beech forests weakly correlated with the lichen species composition $\left(\mathrm{r}^{2}=0.04, p=0.001\right)$. However, several species, e.g. Belonia herculina, Biatora epixanthoides, B. vernalis, Collema flaccidum, Nephroma parile, Opegrapha varia and Parmelina pastillifera clearly preferred overmature forests as the relative frequency of these species in overmature forest was much higher than in mature or young forests. The indicator values of these species in overmature forest stands were highly significant (See Table 4 in Appendix 1). Other species, such as Graphis scripta, Lepraria lobificans aggr., 


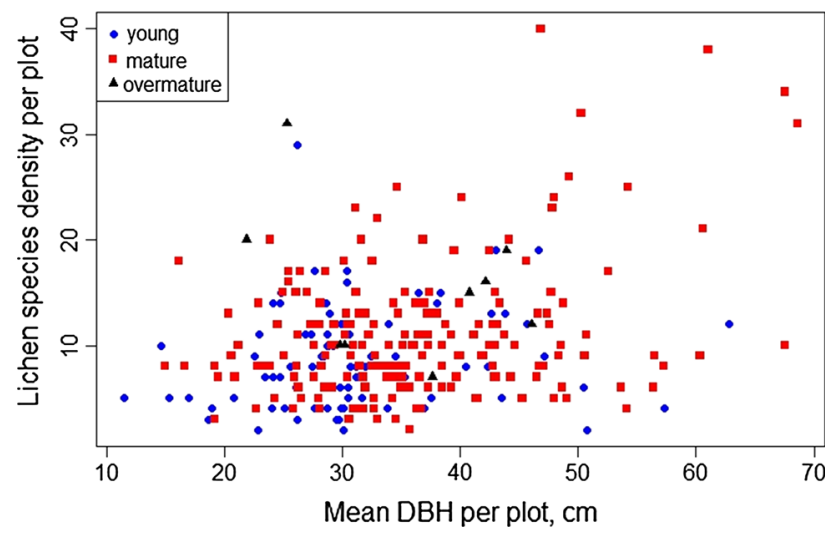

Fig. 4 Relationship between lichen species density and mean DBH of the studied trees $(r=0.56, p<0.05)$ at the sampling plots grouped by the different developmental stages of the forest stands

Phlyctis argena and Pyrenula nitida, had similar relative frequencies in all classes of forest stage and thus their indicator values for stand stages were correspondingly insignificant.

Occurrence of rare and red-listed lichen species

Red-listed species were found on 99, i.e. one third, of the studied plots. The maximum number of red-listed species per sampling plot was four, recorded only once, and the mean number was 0.5 . At the plot level, the red-listed species density correlated highly with the total lichen species density $(\mathrm{r}=0.51, p<0.05)$. Most topographic variables, in particular, the relief, aspect and slope, had no effect on the occurrence of red-listed lichens. According to the GLM analysis, at the plot level the most important factor influencing the density of the red-listed lichen species was altitude (Fig. 8).

\section{Discussion}

Altitude influences lichen species density and composition

Altitude was the most important factor explaining lichen species composition and density at the plot level (Table 3; Figs. 3, 5, 8). Altitude is an indirect climatic variable connected with temperature and precipitation, and is thus widely used as a surrogate for climate (Will-Wolf et al. 2006; Moning et al. 2009). Because many lichens are aero-hygrophytic (Pirintsos et al. 1995; Scheidegger et al. 1995; Nascimbene et al. 2007), the high humidity due to fog and low-lying clouds at high altitudes favours the occurrence of lichen species, including many cyanolichens. Our results confirm previous findings that the high humidity is associated with more diverse lichen communities (Heylen et al. 2005; Pirintsos et al. 1995; Ozturk et al. 2010; Werth et al. 2005). The various microclimatic and light parameters related to the interaction of the altitudinal gradient and forest-structure factors are likely to simultaneously affect lichen species density. 


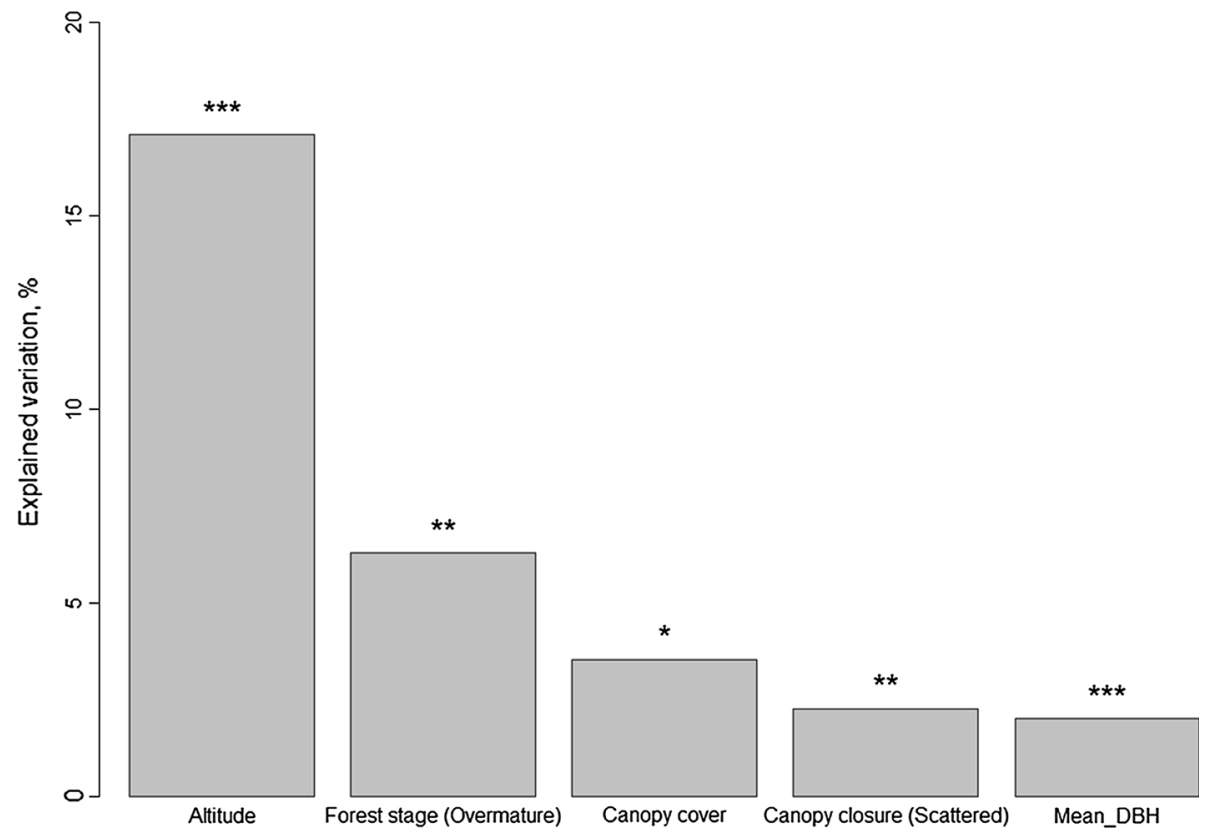

Fig. 5 The variation in lichen species density explained by environmental variables according to GLM analysis. The final model explains $35.1 \%$ of total variation. Significance levels: $* * * p<0.001, * * p<$ $0.01, * p<0.05$

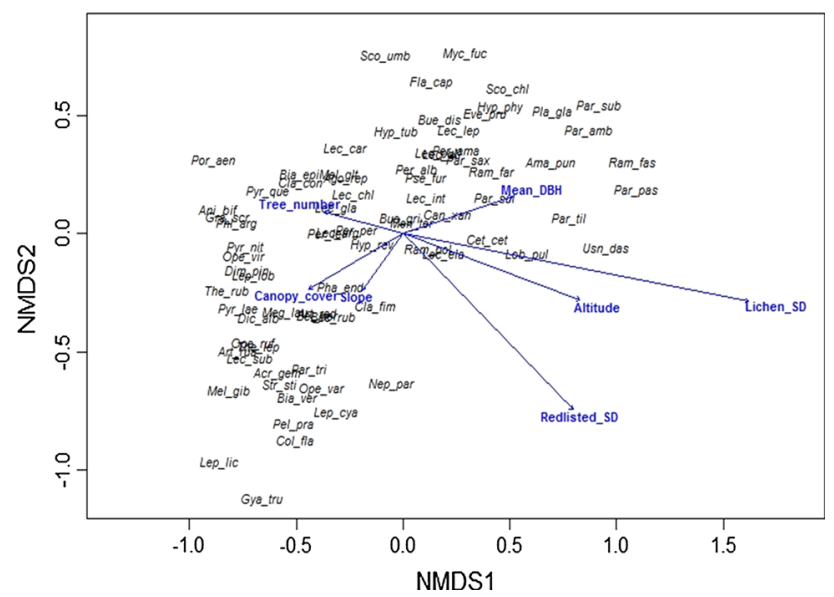

Fig. 6 Non-metric multidimensional scaling (NMDS) ordination of species based on lichen species composition at the plot level. Bray-Curtis distance was used. Correlations with statistically significant environmental variables and responses $(p<0.05)$ are shown. Only lichen species with frequency $>5$ are shown. See Table 4 in Appendix 1 for species abbreviations and Table 1 for an explanation of the variables

Lichen species density may, however, also increase at higher altitudes due to human impact, especially in the form of traditional livestock pasturing on mountain meadows. At $1,100 \mathrm{~m}$ a.s.l. and above, beech trees grow in the ecotone belt, where each summer sheep and goat grazing is rather intensive. The proximity of sheep flocks to the forest might lead 


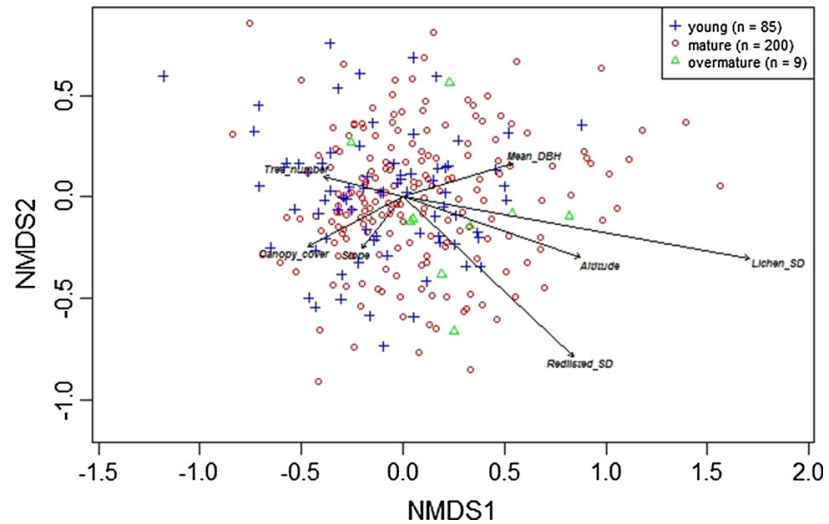

Fig. 7 Non-metric multidimensional scaling (NMDS) ordination of the sampling plots. Bray-Curtis distance was used. The biplot shows the three developmental stages of forest stands: young, mature and overmature. Correlations with statistically significant environmental variables and responses $(p<0.05)$ are shown. See Table 1 for an explanation of the variables

Table 3 Pearson correlation coefficients, coefficients of determination $\left(r^{2}\right)$ and $p$-value of the MNDS ordination axes with environmental variables and responses

\begin{tabular}{|c|c|c|c|c|c|}
\hline Variables & Axis 1 & Axis 2 & $\mathrm{r}^{2}$ & $P$ & \\
\hline \multicolumn{6}{|l|}{ Responses } \\
\hline Lichen_SD & 0.98 & -0.17 & 0.75 & 0.001 & $* * *$ \\
\hline Redlisted_SD & 0.73 & -0.68 & 0.33 & 0.001 & $* * *$ \\
\hline \multicolumn{6}{|c|}{ Environmental variables } \\
\hline Altitude & 0.94 & -0.32 & 0.21 & 0.001 & $* * *$ \\
\hline Mean_DBH & 0.96 & 0.29 & 0.08 & 0.001 & $* * *$ \\
\hline Canopy_cover & -0.88 & -0.47 & 0.07 & 0.001 & $* * *$ \\
\hline Tree_number & -0.97 & 0.24 & 0.04 & 0.003 & $* *$ \\
\hline Slope & -0.63 & -0.78 & 0.03 & 0.019 & $*$ \\
\hline Aspect & -0.63 & -0.78 & 0.01 & 0.619 & \\
\hline Lying deadwood & -0.07 & 0.99 & 0.01 & 0.922 & \\
\hline Canopy closure & - & - & 0.05 & 0.001 & $* * *$ \\
\hline Forest stage & - & - & 0.04 & 0.001 & $* * *$ \\
\hline Relief & - & - & 0.05 & 0.002 & $* *$ \\
\hline
\end{tabular}

$* * * p<0.001, * * p<0.01, * p<0.05$

to nutrient-rich deposits, which may promote the development of nitrophilous epiphytic lichens on Fagus trunks nearby the meadows. These lichens include: Amandinea punctata, Candelariella xanthostigma, Lecanora polytropa, Phaeophyscia orbicularis, Physcia adscendens, Xanthoria fulva, Xanthoria parietina, Xanthoria ulophyllodes and Caloplaca spp. (Barkman 1958; Wirth 1995), which are otherwise rare in beech forests. However, their occurrence may also be explained by the activity of wood-decaying fungi. Fritz and Heilmann-Clausen (2010) showed that the surface of beech bark is often enriched by nutrients from mould in holes with rot. Indeed, the bark of old beech trees growing near the 


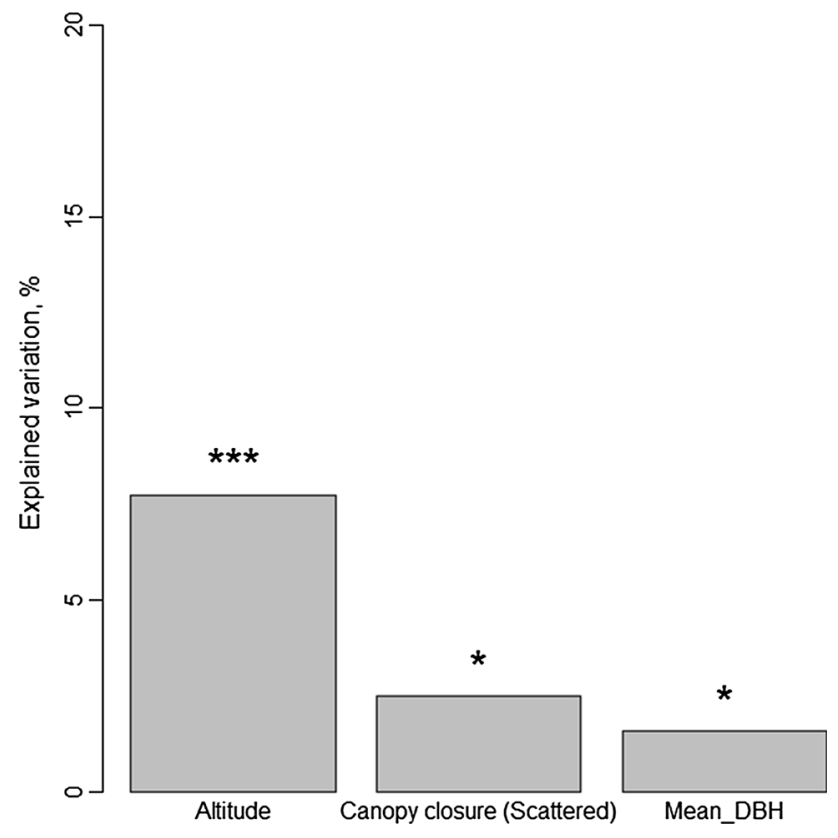

Fig. 8 The variation in species density of red-listed lichens explained by environmental variables according to GLM analysis. The final model explains $17.5 \%$ of total variation. Significance levels: $* * * p<0.001$, $* * p<0.01, * p<0.05$

meadows in Uholka-Shyrokyi Luh area is often damaged by lightning or wood-decaying fungi that favour the formation of cankers and holes with a nutrient-enriched bark surface.

Forest stand structure affects lichen species density

We found a strong relationship between lichen species density and forest-stand variables that reflect the light conditions on the trunks, e.g. canopy closure and canopy cover. This correlation confirms trends found in managed forest stands (Barkman 1958; Löbel et al. 2006; Moning et al. 2009) and some old-growth coniferous forests (Marmor et al. 2011a). A low canopy closure had a positive effect on lichen species density. We showed that the density of lichen species was significantly higher on plots with a relatively open canopy than on plots with fairly loose or very dense canopy structure (Fig. 2b). Since lichen diversity in pure beech forests is known to be low due to limited light (Watson 1936), our results correspond with those of other studies that emphasize the importance of sufficient solar radiation for a high lichen species density.

Canopy closure is a key forest parameter, which reflects not only the developmental stage of forest stands, but also the vertical and horizontal forest structure, including natural disturbances such as wind or snowstorms. Canopy closure is also indirectly related to air humidity and light availability at sampling plots (Commarmot et al. 2013). Forest stands with a scattered canopy transmit more light, but their average air humidity trends to be lower in stands with loose or closed canopy. The availability of more light positively affects the growth of most foliose and fruticose lichens (Barkman 1958; Moning et al. 2009). Thus stands with a scattered canopy favour the occurrence of light-demanding lichens, such as Flavoparmelia caperata, Lecanora argentata, Parmelia sulcata and 
Parmelina tiliacea, while stands with a dense canopy harbour more shade-tolerant lichens, e.g. Belonia herculina, Gyalecta truncigena, Parmeliella triptophylla, Strigula stigmatella. On the other hand, previous studies indicated that logging suddenly increases the solar radiation on any remaining trees, which may lead to light intensities that are lethal for several old-growth forest lichens (Gauslaa and Solhaug 2000). Many lichens associated with old-growth forests reproduce by thallus fragmentation, readily detached lobules or soredia and their dispersal is limited (Sillet et al. 2000; Scheidegger and Werth 2009). The natural death of old beech trees, which may result in scattered forest stands, can also lead to a decrease in many indicator and red-listed lichens, as they often have a low dispersal ability. Canopy closure is thus a complex forest-stand parameter, which is interrelated to several other interdependent variables, including solar radiation, humidity and forest age, and has a strong effect on the pattern of lichen occurrence in beech forests.

\section{Mean stem diameter influences lichen species density}

We showed that the mean DBH is one of the most important factors determining the lichen species density and composition on the sampling plots (Tables 2, 3; Figs. 4, 5, 8). Our results confirm findings of previous studies, which revealed a strong positive correlation between mean DBH and lichen species richness (Aude and Poulsen 2000; Fritz et al. 2008a, b; Mikhailova et al. 2005; Löbel et al. 2006; Mežaka et al. 2008, 2012).

Friedel et al. (2006) pointed out that the diameter of trees at breast height provides an indication of the microhabitat diversity required for tree colonization by epiphytic lichens, which includes bark $\mathrm{pH}$ and the presence of crevices. Commarmot et al. (2013) showed that, most types of microhabitats, such as bark damage, cracks, holes and cavities, were related to tree age and occur mainly in old trees with a mean DBH of 35-44 cm in UholkaShyrokyi Luh. Our study showed that species richness of epiphytic lichens was highest ( $>30$ species per tree) on old and overmature beech trunks growing at higher altitudes where they had a very uneven and often damaged bark structure with cracks and cavities. Thus we can conclude that DBH and bark structure, which correlate with tree age, influence lichen species diversity at the plot level substantially.

In our study we tested the developmental stage of forest stands to approximately assess the age and bark features of beech trees. We found that the late developmental stage of forest stands, which is characterized by a large number of old trees with rough and creviced bark, had a significant positive effect on lichen species density (Table 2; Fig. 5). The composition of lichen species at the plot level was, however, only weakly correlated with a stand's developmental stage (Table 3; Fig. 7) because the forests we studied generally have an uneven-aged stand structure (Trotsiuk et al. 2012; Hobi 2013). This means that, on each plot, trees of different age classes are mixed, which is beneficial for lichen diversity as they vary greatly in their preferences for age classes and bark structure properties. The presence of even just one old tree on a sampling plot with mainly young beeches, which harbours many old-growth lichen species and indicators of woodland key habitat, is very likely to considerably promote lichen species density. In most managed forest landscapes, in contrast, old-growth forest lichens are often restricted to protected stands with oldgrowth characteristics but not to isolated old trees in otherwise young forests (Frey 1958).

Importance of Uholka-Shyrokyi Luh for the conservation of forest-bound lichens

Among the total epiphytic lichens recorded, 13 nationally red-listed species were found in Uholka-Shyrokyi Luh (See Table 4 in Appendix 1). These make up $25 \%$ of all the lichen 
species included in the Ukrainian Red Data Book (Didukh 2009). Furthermore, 35 lichen species are known as indicators of ecological forest continuity (Coppins and Coppins 2002; Kondratyuk 2008) or woodland key habitats (Norén et al. 2002; Ek et al. 2002), e.g. Agonimia allobata, Arthonia vinosa, Bacidia subincompta, Biatora epixanthoides, Leptogium cyanescens, L. lichenoides, Megalaria laureri, Menegazzia terebrata, P. crinitum, Peltigera collina, Piccolia ochrophora, Porina hibernica, P. leptalea, Pyrenula nitida, Thelopsis rubella, Thelotrema lepadinum, Usnea ceratina and Wadeana dendrographa (See Table 4 in Appendix 1). Among them, the most frequent lichens on the plots studied are: Belonia herculina (found on 61 sampling plots), Lobaria pulmonaria (on 45 plots), Parmeliella triptophylla (on 16 plots), Gyalecta truncigena (on 11 plots) and Nephroma parile (on 10 plots). In Uholka-Shyrokyi Luh, the species with a high national and international conservation value, are Belonia herculina, Biatoridium monasteriense, Gyalecta flotowii, Lecanora intumescens, Lobaria amplissima, Megalaria laureri, Melaspilea gibberulosa, Parmeliella triptophylla, Parmotrema arnoldii, Peltigera collina, Ramonia luteola, Strigula stigmatella, Thelopsis rubella, T. flaveola and Thelotrema lepadinum. These are mostly restricted to old beech trees. Many of these species are also red-listed in other European countries (Cieśliński et al. 2003; Liška et al. 2008; Scheidegger et al. 2002 etc.).

\section{Conclusion}

The epiphytic lichen species density at the plot level in the primeval beech forest of Uholka-Shyrokyi Luh, with its uneven-aged structure, was mainly influenced by altitude and forest-stand variables. These factors are mostly related to light availability (i.e. canopy closure) or habitat diversity (the developmental stages of the forest stands and the mean stem diameter). Thus our results confirm previous studies that found climatic and foreststand variables to be highly relevant for lichen communities (Werth et al. 2005; Giordani 2006; Will-Wolf et al. 2006; Ellis and Coppins 2006; Fritz 2009; Moning et al. 2009; Mežaka et al. 2012). DBH and bark structure both influence lichen species diversity in studied beech forest but are interdependent. Both are important for the maintaining of high lichen species richness, including rare and threatened species. The abundance of epiphytic lichens with national and international conservation value in the Uholka-Shyrokyi Luh primeval forest underlines the international importance of the studied area for the conservation of forest-bound lichens.

Acknowledgments We are grateful to Brigitte Commarmot (Swiss Federal Institute for Forest, Snow and Landscape Research, WSL, Switzerland), Ruedi Iseli (Hasspacher und Iseli GmbH, Switzerland) and Mykola Korol (Ukrainian National Forestry University, Ukraine) for their support and coordination in the framework of this project, and to Sergiy Postoialkin, Anna Naumovych, Vasyl Naumovych (Kherson State University, Ukraine), Olexandr Ordynets (V.N. Karasin Kharkiv National University, Ukraine), Volodymyr Savchyn (Ukrainian National Forestry University, Ukraine), and employees of the Carpathian Biosphere Reserve for assistance with field work. We also would like to special thank Silke Werth (Swiss Federal Institute for Forest, Snow and Landscape Research, WSL, Switzerland) for help with the R-program and Silvia Dingwall (Swiss Federal Institute for Forest, Snow and Landscape Research, WSL, Switzerland) for linguistic corrections to the text. We thank the anonymous referees who helped us to improve the manuscript substantially. This project was funded by the Swiss State Secretariat for Education, Research and Innovation (SERI).

\section{Appendix}

See Table 4. 


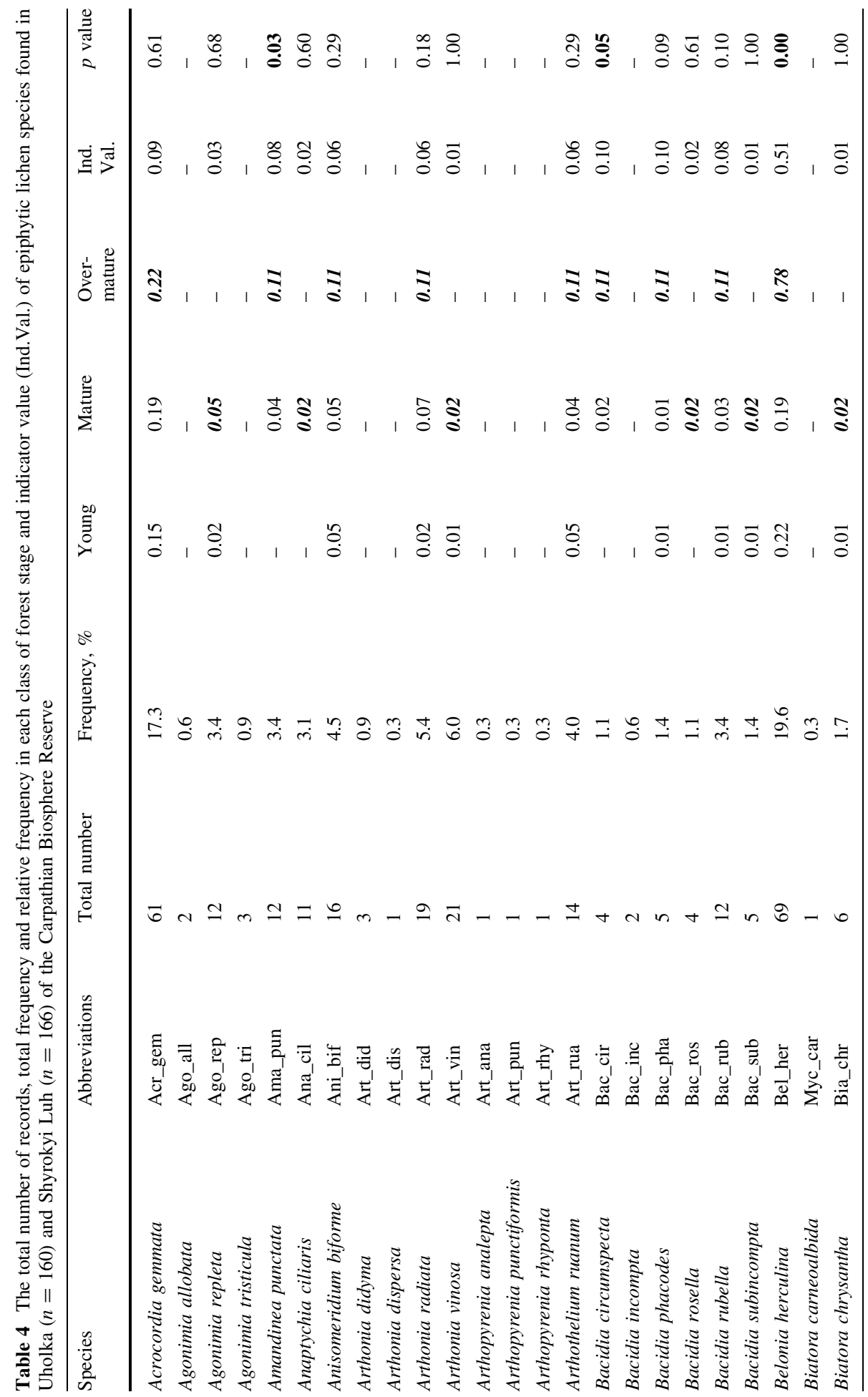




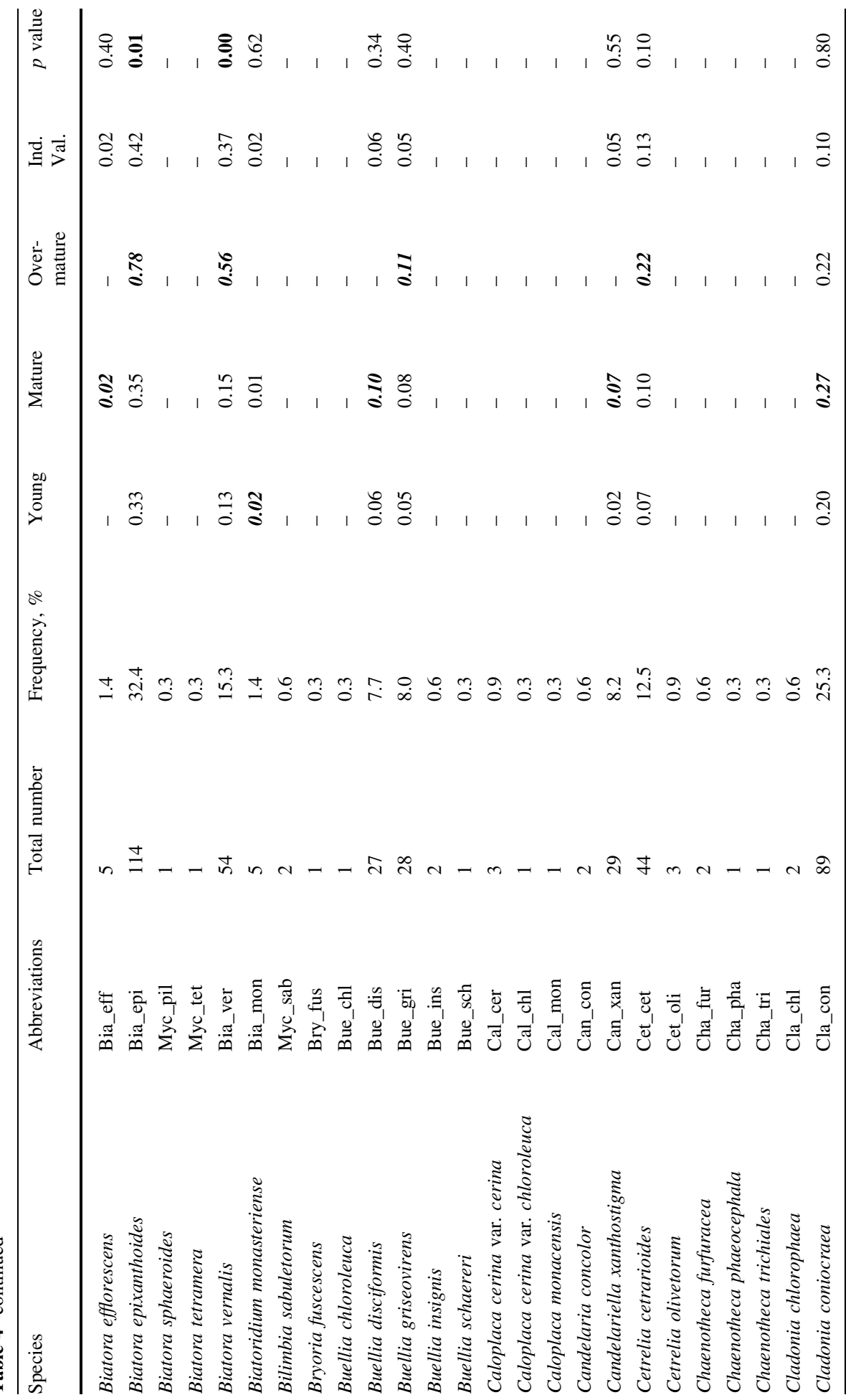




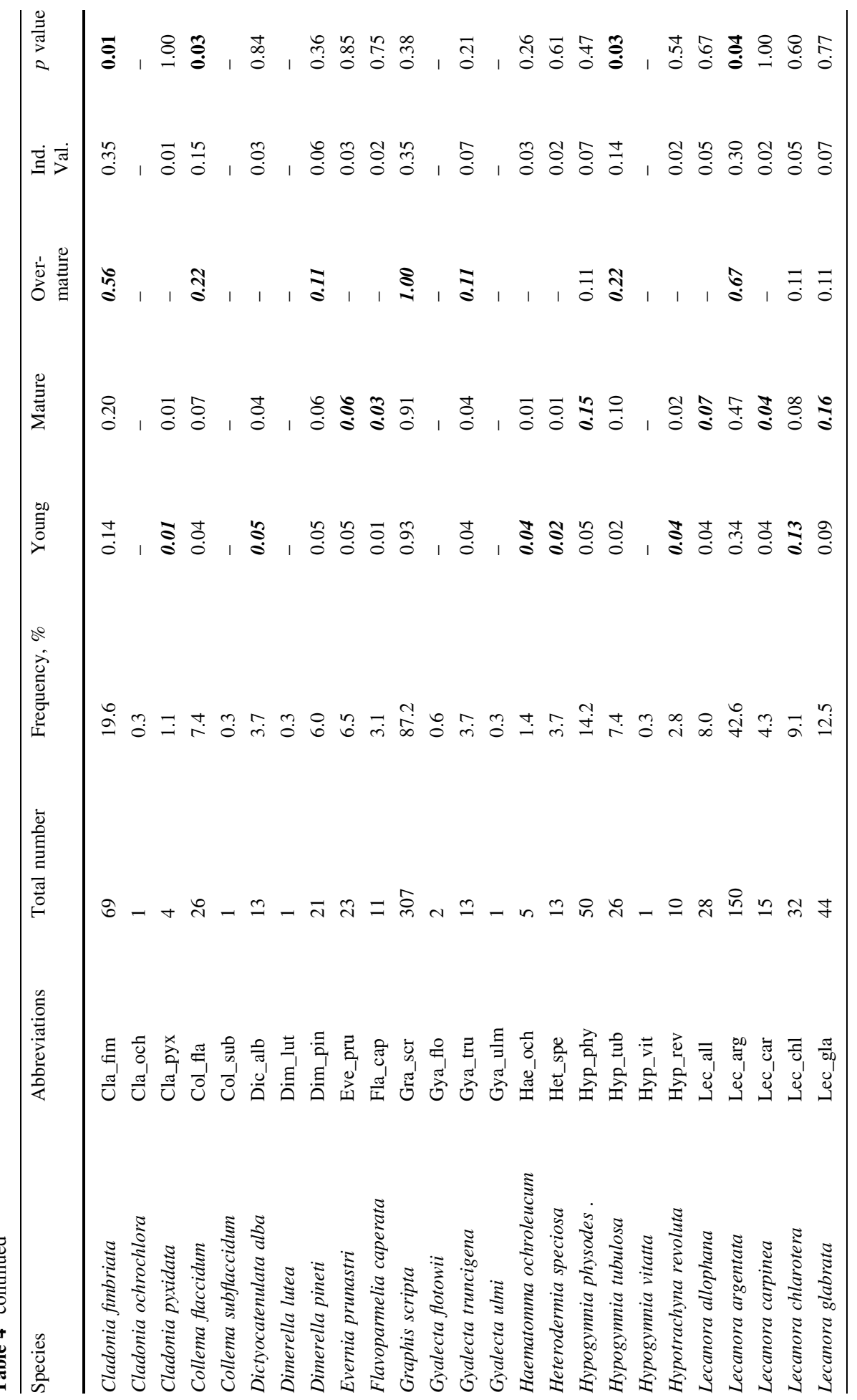




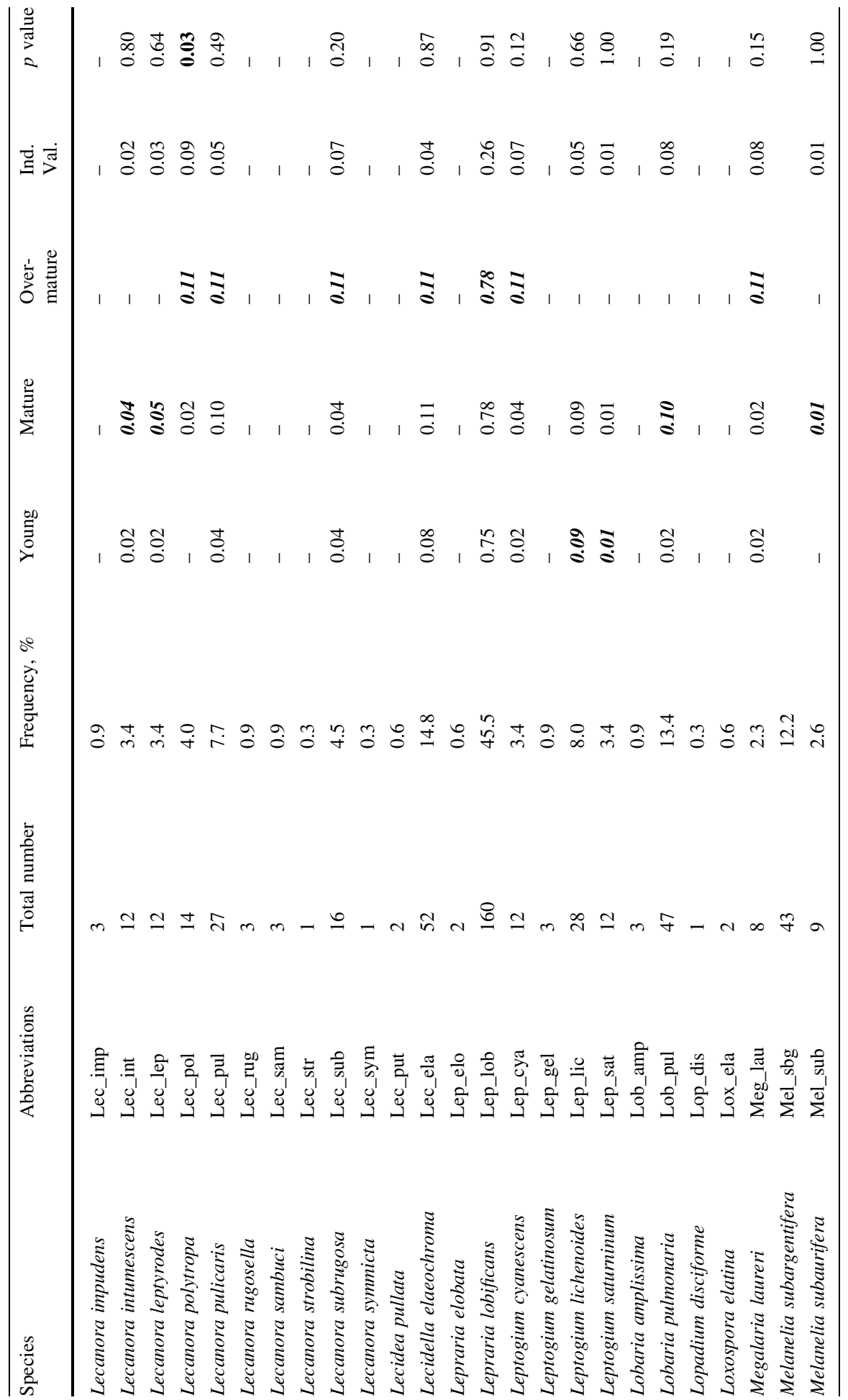




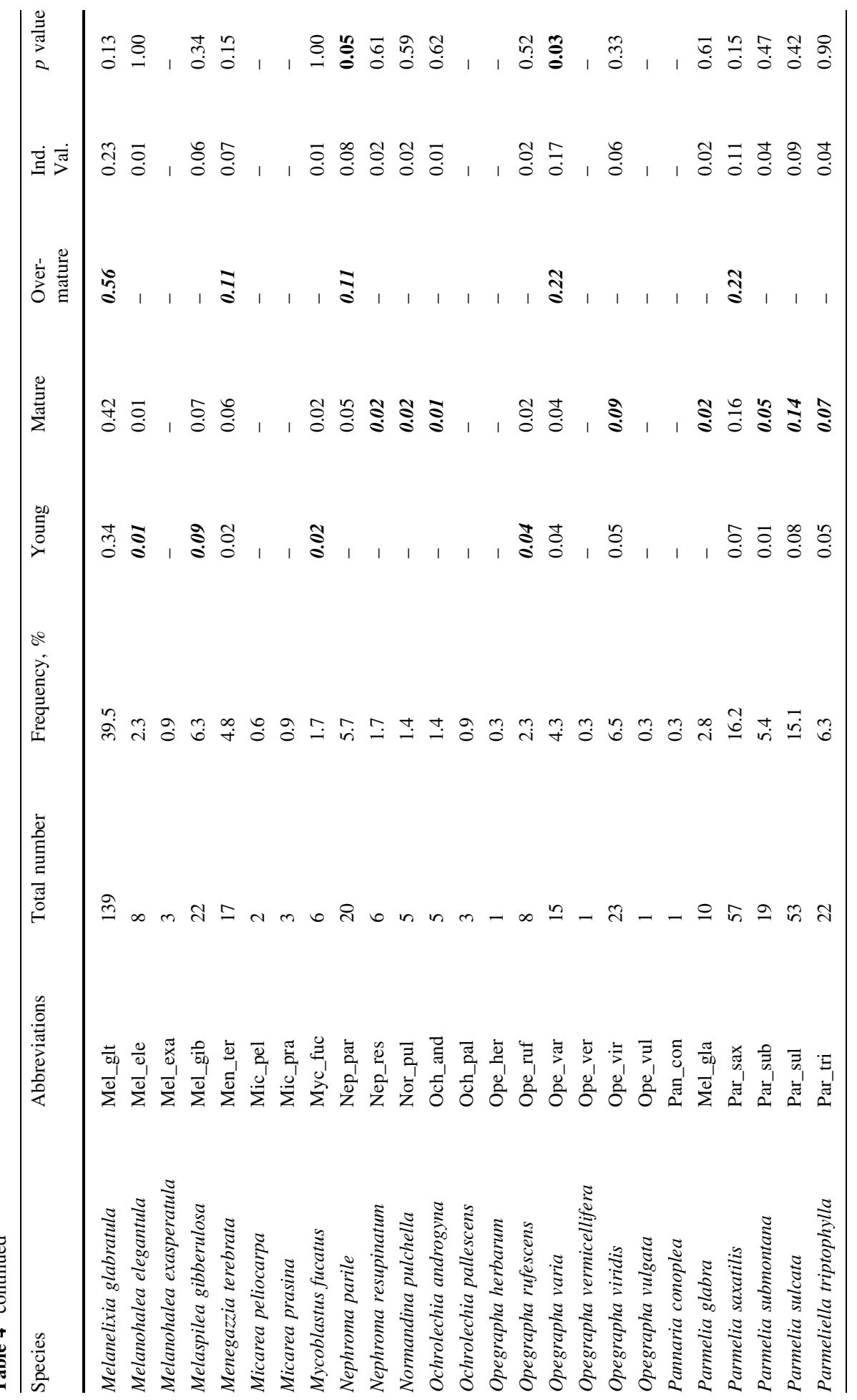




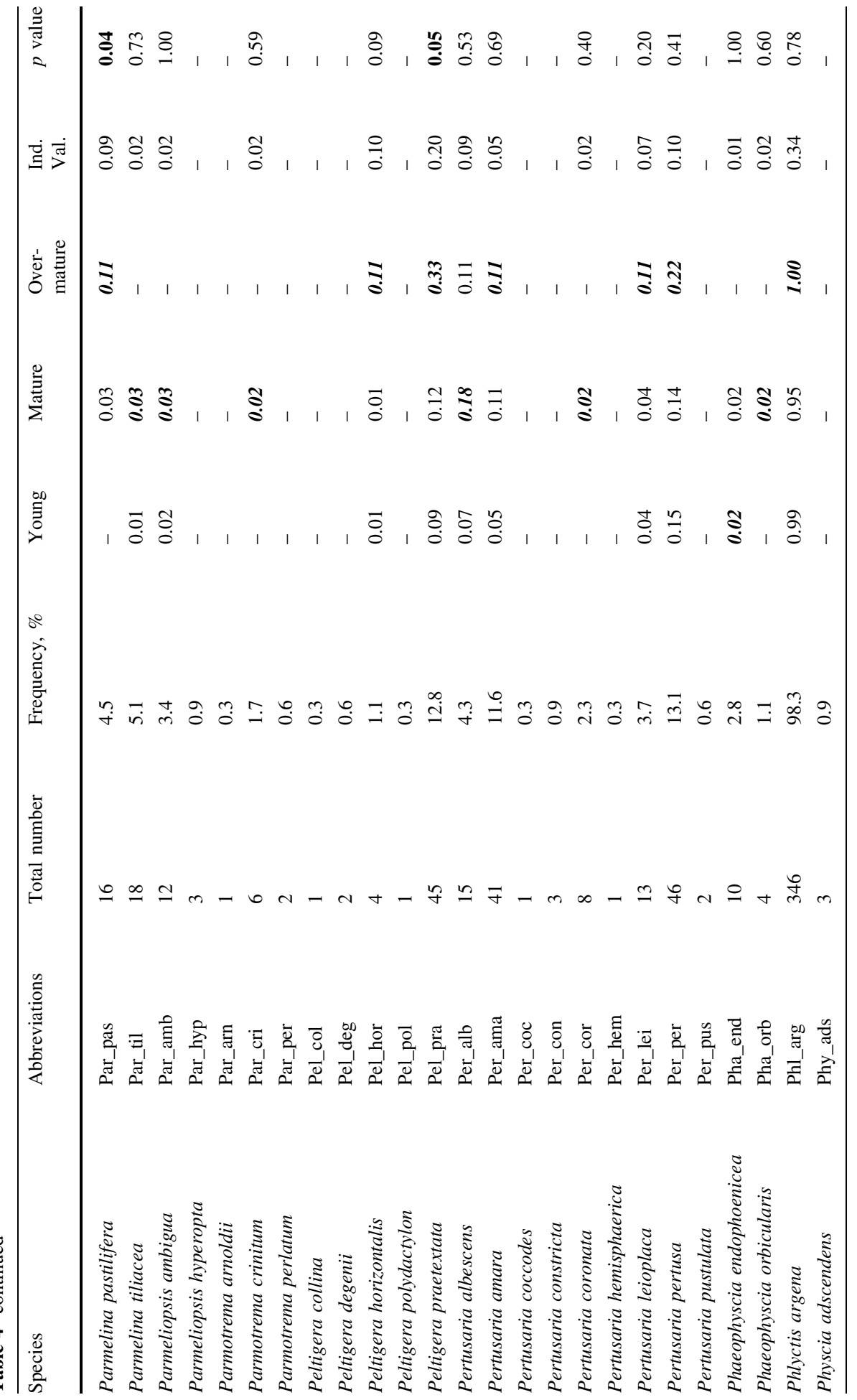




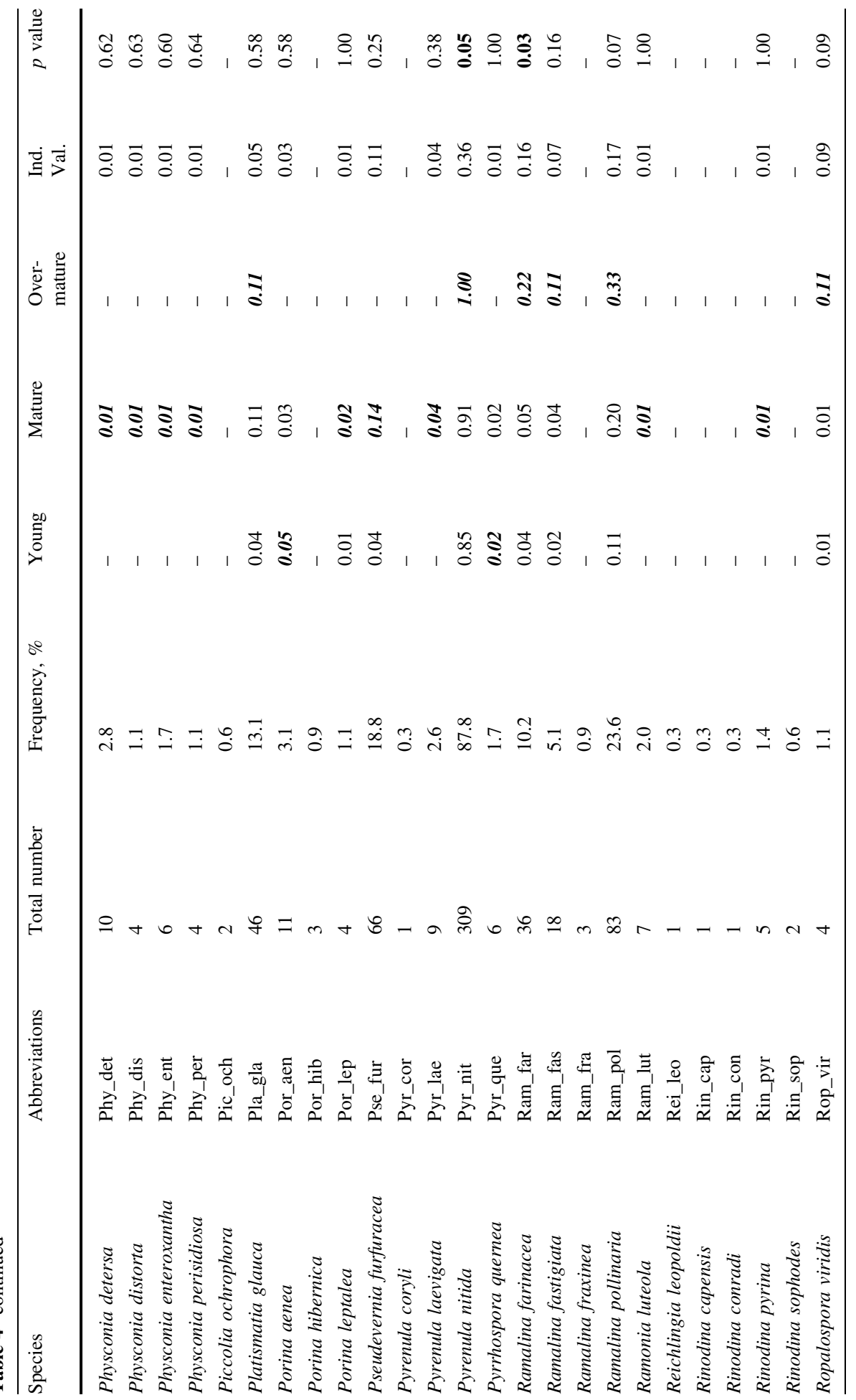




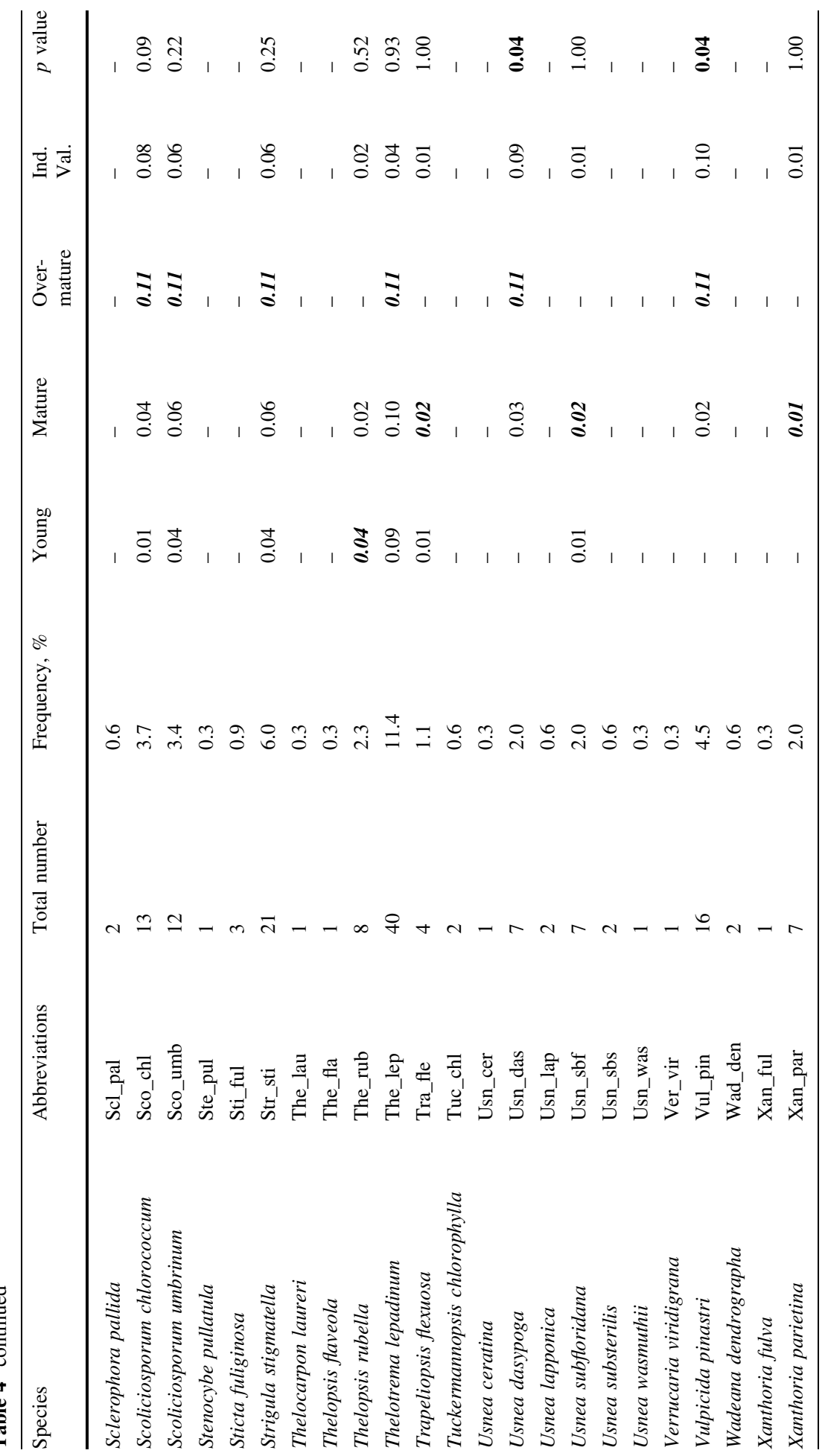




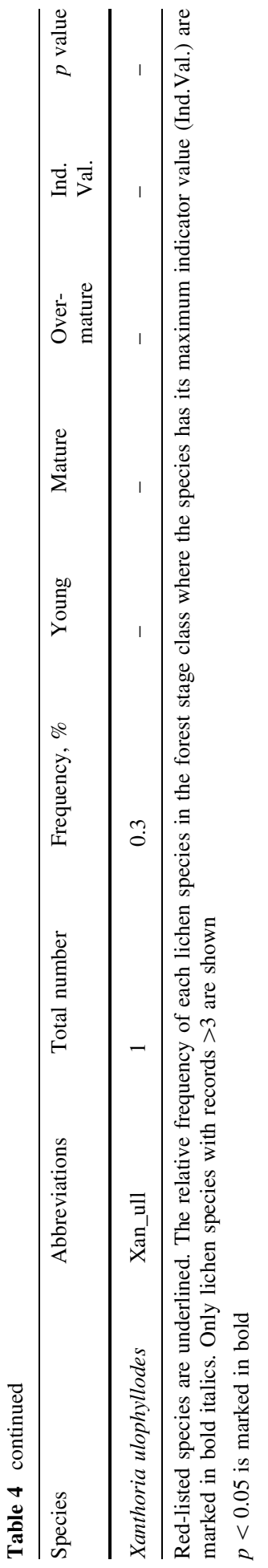




\section{References}

Aude E, Poulsen RS (2000) Influence of management on the species composition of epiphytic cryptogams in Danish Fagus forests. Appl Veg Sci 3:81-88

Barkman JJ (1958) Phytosociology and ecology of cryptogamic epiphytes. Van Gorcum, Assen

Borcard D, Gillet F, Legendre P (2011) Numerical Ecology with R. Springer, New York

Brändli U-B, Dowhanytsch J (2003) Urwälder im Zentrum Europas. Ein Naturführer durch das KarpatenBiosphärenreservat in der Ukraine. Eidgenössische Forschungsanstalt WSL, Rachiw

Bursak VP (1997) The climate. In: Movchan Ya, Hamor F, Sheliag-Sosonko YU, Dudka I, Zahorodniuk I (eds) Biodiversity of the Carpathian Biosphere Reserve. Interecocentr, Kiev, pp 69-80

Cieśliński S, Czyżewska K, Fabiszewski J (2003) Czerwona lista porostów wymarlych i zagrożonych w Polsce. Monographiae Botanicae 91:13-49

Commarmot B, Bachofen H, Bundziak Y, Bürgi A, Ramp B, Shparyk Y, Sukhariuk D, Viter R, Zingg A (2005) Structures of virgin and managed beech forests in Uholka (Ukraine) and Sihlwald (Switzerland): a comparative study. For Snow Landsc Res 79:45-56

Commarmot B, Tinner R, Brang P, Brändli UB (2010) Stichprobeninventur im Buchen-Urwald UholkaSchyrokyj Luh - Anleitung für die Inventur 2010. http://www.wsl.ch/fe/walddynamik/projekte/uholka/ aufnahmenaleitung_de.pdf. Accessed 25 Oct 2011

Commarmot B, Brändli U-B, Hamor F, Lavnyy V, editors. (2013) Inventory of the Largest Primeval Beech Forest in Europe - A Swiss-Ukrainian scientific adventure. WSL Swiss Federal Research Institute, Birmensdorf; Ukrainian National Forestry University, Lviv; Carpathian Biosphere Reserve

Coppins AM, Coppins BJ (2002) Indices of ecological continuity for woodland epiphytic lichen habitats in the British isles. British Lichen Society, Wimbledon

Didukh YP (ed) (2009) The red data book of Ukraine. Plant World. Globalconsulting, Kyiv

Dymytrova L, Nadyeina O, Naumovych G, Keller C, Scheidegger C (2013) Primeval beech forests of Ukrainian Carpathians are sanctuaries for rare and endangered epiphytic lichens. Herzogia 26(1):73-89

Ek T, Suško U, Auzinš R (2002) Inventory of woodland key habitats. Methodology, Riga

Ellis C, Coppins B (2006) Contrasting functional traits maintain lichen epiphyte diversity in response to climate and autogenic succession. J Biogeography 33:1643-1656

Frey E (1958) Die anthropogenen Einflüsse auf die Flechtenflora und -vegetation in verschiedenen Gebieten der Schweiz. Ein Beitrag zum Problem der Ausbreitung und Wanderung der Flechten. Veröffentlichung des Geobotanischen Institutes Rübel in Zürich 33:91-107

Friedel A, Oheimb G, Dengler J, Hardtle W (2006) Species diversity and species composition of epiphytic bryophytes and lichens-a comparison of managed and unmanaged beech forests in NE Germany. Feddes Repertorium 177:172-185

Fritz Ö (2009) Vertical distribution of epiphytic bryophytes and lichens emphasizes the importance of old beeches in conservation. Biodivers Conserv 18:289-304

Fritz Ö, Heilmann-Clausen J (2010) Rot holes create key microhabitats for epiphytic lichens and bryophytes on beech (Fagus sylvatica). Biol Cons 143:1008-1016

Fritz Ö, Gustafsson L, Larsson K (2008a) Does forest continuity matter in conservation? - A study of epiphytic lichens and bryophytes in beech forests of southern Sweden. Biol Conserv 141:655-668

Fritz Ö, Niklasson M, Churski M (2008b) Tree age is a key factor for the conservation of epiphytic lichens and bryophytes in beech forests. Appl Veg Sci 12:93-106

Gauslaa Y, Solhaug KA (2000) High-light-intensity damage to the foliose lichen Lobaria pulmonaria within a natural forest: the applicability of chlorophyll fluorescence methods. Lichenologist 32:271-289

Giordani P (2006) Variables influencing the distribution of epiphytic lichens in heterogeneous areas: a case study for Liguria, NW Italy. J Veg Sci 17:195-206

Hamor FD, Berkela YY (2011) A collection of legal and others documents about the activities of the Carpathian Biosphere Reserve. Karpatska veja, Rakhiv

Heylen O, Hermy M, Schrevens E (2005) Determinants of cryptogamic epiphyte diversity in a river valley (Flanders). Biol Conserv 126:371-382

Hnatiuk RM, Zinko YV (1997) Geology and geomorphology. In: Movchan Ya, Hamor F, Sheliag-Sosonko Yu, Dudka I, Zahorodniuk I (eds) Biodiversity of the Carpathian Biosphere Reserve. Interecocentr, Kiev, pp 58-67

Hobi ML (2013) Structure and disturbance patterns of the largest European primeval beech forest revealed by terrestrial and remote sensing data. Ph. D. Thesis No. 21195 ETH Zurich, Zurich. 166 pp

Kondratyuk SY (2008) Indication of the environment of Ukraine using lichens. M.H. Kholodny Institute of Botany, Kyiv 
Kondratyuk SY, Coppins BJ (2000) Basement for the lichen monitoring in Uzhansky National Nature Park (Ukrainian part of the Biosphere Reserve 'Eastern Carpathians'). Roczniki Bieszczadzkie 8:149-192

Kondratyuk SY, Popova LP, Lackovičová A, Pišút I (2003) A catalogue of Eastern Carpathian lichens. M.H. Kholodny Institute of Botany, Kiev

Kondratyuk SY, Dymytrova LV, Nadyeina OV (2010) The third checklist of lichen-forming and allied fungi of Ukraine. In: Roms S (ed) Flora of the lichens of Ukraine. Naukova dumka, Kyiv, pp 446-486

Lanz A (2011) Auswertung von Waldinventuren-Formeln mit Zahlenbeispielen. Arbeitspapier. Eidg. Forschungsanstalt für Wald, Dietikon

Lanz A, Brändli U-B, Commarmot B, Ginzler C (2013) The inventory - aims, methods and sampling design. In: Commarmot B, Brändli U-B, Hamor F, Lavnyy V (eds) Inventory of the Largest Primeval Beech Forest in Europe-A Swiss-Ukrainian scientific adventure. Ukrainian National Forestry University, L'viv

Liška J, Palice Z, Slavíková Š (2008) Checklist and red list of lichens of the Czech Republic. Preslia 80:151-182

Löbel S, Snäll T, Rydin H (2006) Species richness patterns and metapopulation processes-evidence from epiphyte communities in boreo-nemoral forests. Ecography 29:169-182

Magri D, Vendramin GG, Comps B, Dupanloup I, Geburek T, Gömöry D, Latałowa M, Litt T, Paule L, Roure JM, Tantau I, van der Knaap WO, Petit RJ, de Beaulieu JL (2006) A new scenario for the Quaternary history of European beech populations: palaeobotanical evidence and genetic consequences. New Phytol 171:199-221

Mandallaz D (2008) Sampling techniques for forest inventories. Chapman \& Hall/CRC, Boca Raton

Marmor L, Torra T, Leppik E, Saag L, Randlane T (2011a) Epiphytic lichen diversity in Estonian and Fennoscandian old coniferous forests. Folia Cryptogam Est 48:31-43

Marmor L, Torra T, Saag L, Randlane T (2011b) Effects of forest continuity and tree age on epiphytic lichen biota in coniferous forest in Estonia. Ecol Indic 11:12170-12176

Mežaka A, Brūmelis G, Piterāns A (2008) The distribution of epiphytic bryophyte and lichen species in relation to phorophyte characters in Latvian natural old-growth broad leaved forests. Folia Cryptogam Est 44:89-99

Mežaka A, Brūmelis G, Piterāns A (2012) Tree and stand-scale factors affecting richness and composition of epiphytic bryophytes and lichens in deciduous woodland key habitats. Biodivers Conserv 21(12):3221-3241

Mikhailova I, Trubina M, Vorobeichik E, Scheidegger C (2005) Influence of environmental factors on the local-scale distribution of cyanobacterial lichens: case study in the North Urals, Russia. Folia Cryptogam Est 41:45-54

Moning C, Müller J (2009) Critical forest age thresholds for the diversity of lichens, molluscs and birds in beech (Fagus sylvatica) dominated forests. Ecol Indic 9(5):922-932

Moning C, Werth S, Dziock F, Bässler C, Bradtka J, Hothorn T, Müller J (2009) Lichen diversity in temperate montane forests is influenced by forest structure more than climate. For Ecol Manage 258(5):745-751

Nascimbene J, Marini L, Nimis PL (2007) Influence of forest management on epiphytic lichens in a temperate beech forest on northern Italy. For Ecol Manage 247:43-47

Navrotska IL (1984) Lichen flora of beech forests in the plain part of Ukraine. Ukr Bot Z 41(1):44-54

Norén M, Nitare J, Larsson A, Hultgren B, Bergengren I (2002) Handbok för inventering av nyckelbiotoper. Skogsstyrelsen, Jönköping

Oksanen J (2011) Multivariate analysis of ecological communities in R: vegan tutorial

Oksanen J, Blanchet GF, Kindt R, Legendre P, Minchin PR, O’Hara RB, Simpson GL, Solymos P, Stevens HM, Wagner H (2012) Community Ecology Package. Package 'vegan'. http://vegan.r-forge.r-project. org/. Accessed 25 Oct 2012

Ozturk S, Oran S, Guvenc S, Dalkiran N (2010) Analysis of the distribution of epiphytic lichens in the oriental beech (Fagus orientalis) forests along an altitudinal gradient in Uludag mountain, BursaTurkey. Pak J Bot 42(4):2661-2670

Pirintsos SA, Diamantopoulos J, Stamou GP (1995) Analysis of the distribution of epiphytic lichens within homogenous Fagus sylvatica stands along an altitudinal gradient (Mount Olympos, Greece). Vegetatio 116:33-40

Printzen C, Halda J, Palice Z, Tønsberg T (2002) New and interesting lichen records from old-growth forest stands in the German National Park Bayerischer Wald. Nova Hedwig 74(1-2):25-49

Roberts D (2011) Ordination and multivariate analysis for ecology. Package 'labdsv'. http://ecology.msu. montana.edu/labdsv/R. Accessed 3 Oct 2012

Scheidegger C, Werth S (2009) Conservation strategies for lichens: insights from population biology. Fungal Biol Rev 23:55-66 
Scheidegger C, Schroeter B, Frey B (1995) Structural and functional processes during water vapour uptake and desiccation in selected lichens with green algal photobionts. Planta 197:399-409

Scheidegger C, Clerc P, Dietrich M, Frei M, Groner U, Keller C, Roth I, Stofer S, Vust M (2002) Liste Rouge des espèces menacées en Suisse. Lichens épiphytes et terricoles. http://www.bafu.admin.ch/ publikationen/publikation/00915/index.html. Accessed May 2011

Sheliag-Sosonko YR, Popovych SY, Ustymenko PM (1997) Diveristy of cenosis in Uholskoshyrokoluhanskyi reserved massif. In: Movchan YA, Hamor F, Sheliag-Sosonko Yu, Dudka I, Zahorodniuk I (eds) Biodiversity of the Carpathian Biosphere Reserve. Interecocentr, Kiev, pp 132-145

Sillet SC, McCune B, Peck JE, Rambo TR, Ruchty A (2000) Dispersal limitations of epiphytic lichens result in species dependent on old-growth forests. Ecol Appl 10(3):789-799

Trotsiuk V, Hobi ML, Commarmot B (2012) Age structure and disturbance dynamics of the relic virgin beech forest Uholka (Ukrainian Carpathians). For Ecol Manage 265:181-190

Vondrák J, Palice Z, Khodosovtsev A, Postoyalkin S (2010) Additions to the diversity of rare or overlooked lichens and lichenicolous fungi in Ukrainian Carpathians. Chornomors'kyi Bot J 6:6-34

Watson W (1936) The bryophytes and lichens of British woods. Part 1. Beechwoods. J Ecol 24:139-161

Werth S, Tømmervik H, Elvebakk A (2005) Epiphytic macrolichen communities along regional gradients in northern Norway. J Veg Sci 16:199-208

White FJ, James PW (1985) A new guide to microchemical techniques for the identification of lichen substances. Br Lichen Society Bull 57(suppl):1-41

Will-Wolf S, Geiser LH, Neitlich P, Reis AH (2006) Forest lichens communities and environment-how consistent are relationships across scales? J Veg Sci 17:171-1844

Wirth V (1995) Die Flechten Baden-Württembergs. Eugen Ulmer, Stuttgart 